\title{
Cohort growth and survival of bay anchovy Anchoa mitchilli larvae in Biscayne Bay, Florida*
}

\author{
James C. Leak ${ }^{1} \&$ Edward D. Houde $\mathrm{e}^{2, * *}$ \\ ${ }^{1} 640$ SW 28 Road, Miami, Florida 33129, USA \\ ${ }^{2}$ University of Maryland Center for Environmental and Estuarine Studies, Chesapeake Biological Laboratory, PO Box 38 , \\ Solomons, Maryland 20688, USA
}

\begin{abstract}
Egg and larval abundance of bay anchovy Anchoa mitchill from 4 field experiments in Biscayne Bay, Florida, were analyzed to determine variability in growth and mortality rates of dailyspawned cohorts. Mean egg densities varied by more than an order of magnitude in the 4 experiments. Otolith-aged larvae, validated by laboratory rearing, were used to construct the age-frequency distributions of 71 cohorts. Mean growth rate estimates ranged from 0.43 to $0.56 \mathrm{~mm} \mathrm{~d}^{-1}$ and the means of cohort-specific instantaneous mortality rates ranged from 0.30 to $0.45\left(26\right.$ to $\left.36 \% \mathrm{~d}^{-1}\right)$. Egg mortality rates were generally higher and more variable than those for larvae. An approximate mean instantaneous mortality rate for eggs was $1.94\left(85.6 \% \mathrm{~d}^{-1}\right)$. Mean larval growth and mortality rates differed significantly among experiments, although reasons for the differences were not identified. On average, relative survivals of cohorts varied by a factor of 20 at $20 \mathrm{~d}$ after hatching among the 4 experiments. Estimated mean abundances of larval cohorts at $20 \mathrm{~d}$ varied by a factor of 45 , reflecting differences in initial abundances of eggs and the variable mortality rates. Models of bay anchovy growth and mortality in relation to prey concentration, developed in previous laboratory experiments, were used to partition field-experiment mortalities into nutrition-related and presumed predation-related components. Mean daily losses of a cohort to predation (18 to $28 \%$ ) were 2 to 3 times higher than losses to starvation (10 to $11 \%$ ).
\end{abstract}

\section{INTRODUCTION}

High mortality rates, generally attributed to predation or starvation of embryos and larvae (Hunter 1981), can lead to major fluctuations in recruitment and abundance of stocks (Cushing 1975). The application of otolith-aging techniques to the larval stage of marine fishes (Brothers et al. 1976, Struhsaker \& Uchiyama 1976) has facilitated determination of age and growth and also estimation of mortality rates in the larval stage (Hewitt \& Methot 1982, Methot 1983, Graham \& Townsend 1985). It is now possible to sample daily cohorts of larvae to estimate their growth and mortality rates, which is particularly valuable for species with protracted spawning seasons that may experience significant day-to-day or seasonal variability in survival (Crecco \& Savoy 1985, Essig \& Cole 1986). In this study 4 field experiments were carried

\footnotetext{
- Contribution No. 1793 of the Center for Environmental and Estuarine Studies of the University of Maryland

- Addressee for reprint requests
}

out in Biscayne Bay, Florida, to determine how abundance, growth and survival of bay anchovy Anchoa mitchilli larvae varied seasonally or relative to microzooplankton abundances and presumed predator densities. The research was designed to compare growth and survival in the Bay with that previously observed in extensive laboratory studies (Detwyler \& Houde 1970, Houde 1977, Houde \& Schekter 1981), and to ascertain if daily cohorts in Biscayne Bay experienced highly variable survival rates.

Bay anchovy is one of the most abundant fishes in coastal waters from Cape Cod to Yucatan (Bigelow \& Schroeder 1953). Its larvae are usually the dominant ichthyoplankton species in estuaries within that range (e.g. Pearson 1941, Dovel 1971, 1981, Flores-Coto et al. 1983, Houde \& Lovdal 1984). In Biscayne Bay, bay anchovy has a protracted spawning season that runs from February through November. It contributes $56 \%$ to the fish egg and $20 \%$ to the fish larvae catches annually, with much higher relative contributions from April to October, the peak months of spawning (Houde \& Lovdal 1984). 


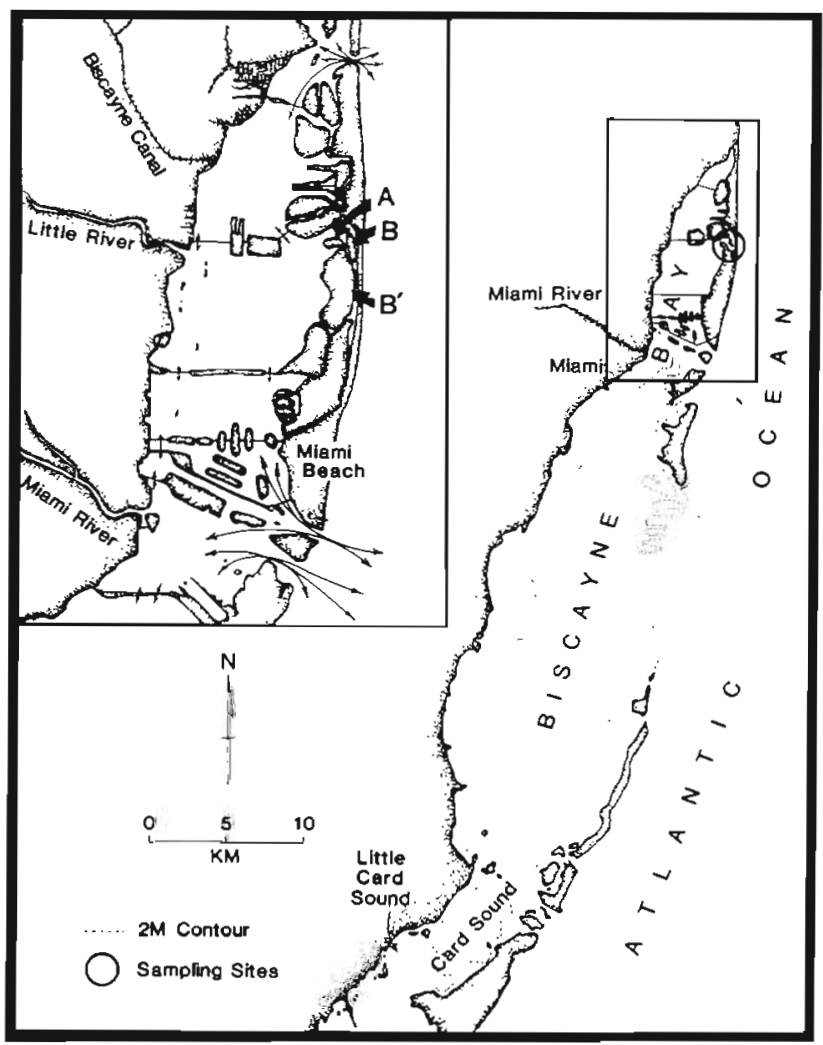

Fig. 1. North Biscayne Bay Florida, USA, and the 2 sampling sites

\section{METHODS}

Study site. Biscayne Bay is a shallow, subtropical lagoon approximately $60 \mathrm{~km}$ long and $15 \mathrm{~km}$ wide (Fig. 1). Mean depth is $2.0 \mathrm{~m}$ and maximum depth is $3.5 \mathrm{~m}$. It consists of a large southern basin which is contiguous with Card Sound and a smaller, relatively isolated northern basin where this study was carried out. North Biscayne Bay is only $5 \mathrm{~km}$ wide (Fig. 1 inset) and water circulation is restricted by 6 man-made causeways and many man-made and natural islands. Currents in northern Biscayne Bay are primarily tidally-induced despite the small tidal range of only $57 \mathrm{~cm}$ (Hela et al. 1957). Isolated subareas and limited water exchange in North Biscayne Bay were desirable characteristics which preserved the integrity of the water mass during a field experiment and facilitated the cohort analysis.

Although Biscayne Bay is subtropical, there is considerable seasonal variation in temperature and salinity. In a 1 yr ichthyoplankton survey Houde \& Lovdal (1984) recorded mean water-column temperatures from 14.2 to $31.8{ }^{\circ} \mathrm{C}$ and salinities from 26.0 to $36.5 \%$.

Sampling sites and dates. Two sites were sampled (Fig. 1 inset) in the part of North Biscayne Bay where water transport was believed to be minimal (Hela et al.
1957). In the 10 to 21 September 1979 experiment samples were collected within a $1.0 \mathrm{~km}$ radius of Site A. Experiments conducted from 17 to 25 April 1980 , 30 May to 6 June 1980 and 15 to 22 August 1980 were confined to Indian Creek, in the $1.5 \mathrm{~km}$ area designated $B-B^{\prime}$.

Water mass exchange. Rates of water exchange were estimated to determine if it were probable that larvae would be transported from the study area during an experiment. Strong transport or fast water mass replacement might weaken the assumption that a single population of larvae was being sampled. Aqueous solutions of rhodamine WT dye were released at the center of the study site at the beginning of each field experiment and the exponential decline in dye concentration over time, determined by pumping water through a continuous-recording, Turner Model 10 flow-through fluorometer, was used to estimate dilution and water exchange. No estimate was obtained in September 1979 because of fluorometer failure, but 3 good estimates were obtained during the 1980 experiments.

The rate of dye loss from the Indian Creek system is illustrated in Fig. 2. Dye did not exit unidirectionally but dispersed throughout the system and exited slowly via several canals into Biscayne Bay during each ebb tide. Rates of loss per tidal cycle ranged from 13 to $20 \%$ during the 3 experiments and did not differ significantly (analysis of covariance, $p>0.25$ ). The mean rate was $17 \%$ per tidal cycle, giving an expected residence time of the water mass (time until $95 \%$ was exchanged) of $8 \mathrm{~d}$. It is possible that significant population exchange could have occurred, especially at Site A in the September 1979 experiment, if spawning by adult anchovies and distribution of eggs/larvae were not spatially and temporally homogeneous in North Biscayne Bay. Preliminary sampling in 1979 (unpubl.

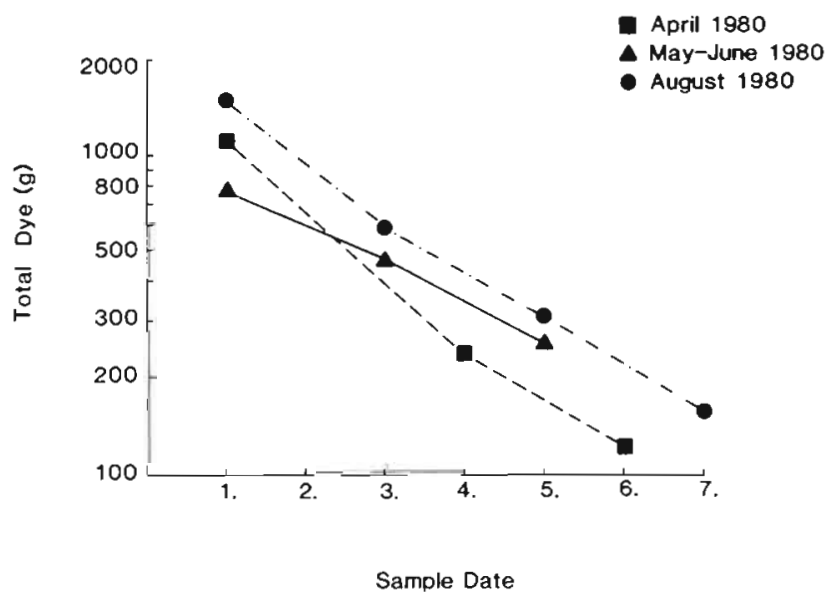

Fig. 2. Declines in amounts of rhodamine dye at the sampling sites in North Biscayne Bay on sequential sampling dates 
Table 1. Summary of sample collection information and temperatures during 4 field experiments in Biscayne Bay

\begin{tabular}{|c|c|c|c|c|c|c|}
\hline $\begin{array}{c}\text { Experi- } \\
\text { ment }\end{array}$ & Dates & $\begin{array}{l}\text { No. of } \\
\text { sampling } \\
\text { dates }\end{array}$ & $\begin{array}{c}\text { No. of } \\
\text { ichthyoplankton } \\
\text { samples }\end{array}$ & $\begin{array}{l}\text { Mean tow } \\
\text { time (min) }\end{array}$ & $\begin{array}{l}\text { No. of microzoo- } \\
\text { plankton samples }\end{array}$ & $\begin{array}{c}\text { Mean sea } \\
\text { temperature }\left({ }^{\circ} \mathrm{C}\right)\end{array}$ \\
\hline 1 & 10-21 Sep 1979 & 6 & 36 & 3 & 6 & 29.0 \\
\hline 2 & 17-25 Арг 1980 & 5 & 25 & 6 & 8 & 24.4 \\
\hline 3 & 30 May-6 Jun 1980 & 5 & 25 & 10 & 8 & 28.1 \\
\hline 4 & 15-22 Aug 1980 & 5 & 25 & 15 & 8 & 30.7 \\
\hline
\end{tabular}

data) indicated that anchovy eggs and larvae were abundant in North Biscayne Bay, to the west of the experimental sampling sites. Because there is no a priori reason to believe that the population at our study site was advected unidirectionally or that it was not part of a larger North Biscayne Bay population, we believe that the modest exchange rate of water was unlikely to have caused a serious loss of larvae that could have contributed significantly to the subsequent estimates of mortality rates.

Field sampling. Ichthyoplankton was collected in $61 \mathrm{~cm}$ bongo nets with $333 \mu \mathrm{m}$ meshes towed at approximately 2 knots from a $6 \mathrm{~m}$ outboard-powered boat. In September 1979 samples were collected near bottom and at surface, but in 1980 oblique tows were used to sample the $3.3 \mathrm{~m}$ depth water column (Table 1). Tows ranged from 3 to $15 \mathrm{~min}$ duration. Volumes filtered were determined from flowmeters in the nets. Ichthyoplankton samples were preserved in $95 \%$ ethanol. Mean sea temperatures and tow durations were also recorded.

Microzooplankton was collected (Table 1) with a positive-pressure diaphragm pump which delivered $201 \mathrm{~min}^{-1}$. The $3.8 \mathrm{~cm}$ diameter intake hose was lifted slowly from bottom to surface to obtain a depth-integrated, $20 \mathrm{l}$ sample which was filtered onto a $20 \mu \mathrm{m}$ nitex screen. Microzooplankton was fixed in $5 \%$ formalin.

Sample processing. Fish eggs and larvae were removed from samples within 5 mo of collection. Bay anchovy larvae were identified and measured (standard length) to the nearest $0.5 \mathrm{~mm}$. Numbers of eggs and larvae in each sample were standardized to numbers per $100 \mathrm{~m}^{3}$ filtered. The $20 \mathrm{l}$ microzooplankton samples were examined and the numbers per $\mathrm{m}^{3}$ of dinoflagellates, tintinnids, polychaete larvae, copepod nauplii, copepod adults and copepodids $<100 \mu \mathrm{m}$ wide, copepods $>100 \mu \mathrm{m}$ wide, cirripede nauplii, porcellanid crab zoeae, gastropods, bivalves, chaetognaths and larvaceans were estimated from counts in aliquots that ranged from $1 / 8$ to $1 / 2$ of the 201 sample.

Otolith daily increment validation. Bay anchovy larvae were reared in the laboratory in $75 \mathrm{l}$ tanks, at $25^{\circ} \mathrm{C}$ with an $11.5 \mathrm{~h}$ light/12.5 h dark cycle. Food was copepod nauplii maintained at $\geq 1000 \mathrm{l}^{-1}$. Rearing methods were essentially those of Houde (1977). Several larvae were removed daily and preserved in $95 \%$ ethanol for growth and otolith increment examination.

The larvae were measured to the nearest $0.5 \mathrm{~mm}$ standard length. Sagittal otoliths were dissected and mounted on a microscope slide in liquid cover-slip mounting medium. Otolith diameters were measured along their longest axis to the nearest $1 \mu \mathrm{m}$ with an ocular micrometer at $400 \times$. Primary growth increments of sagittae from 66 laboratory-reared larvae, 3 to

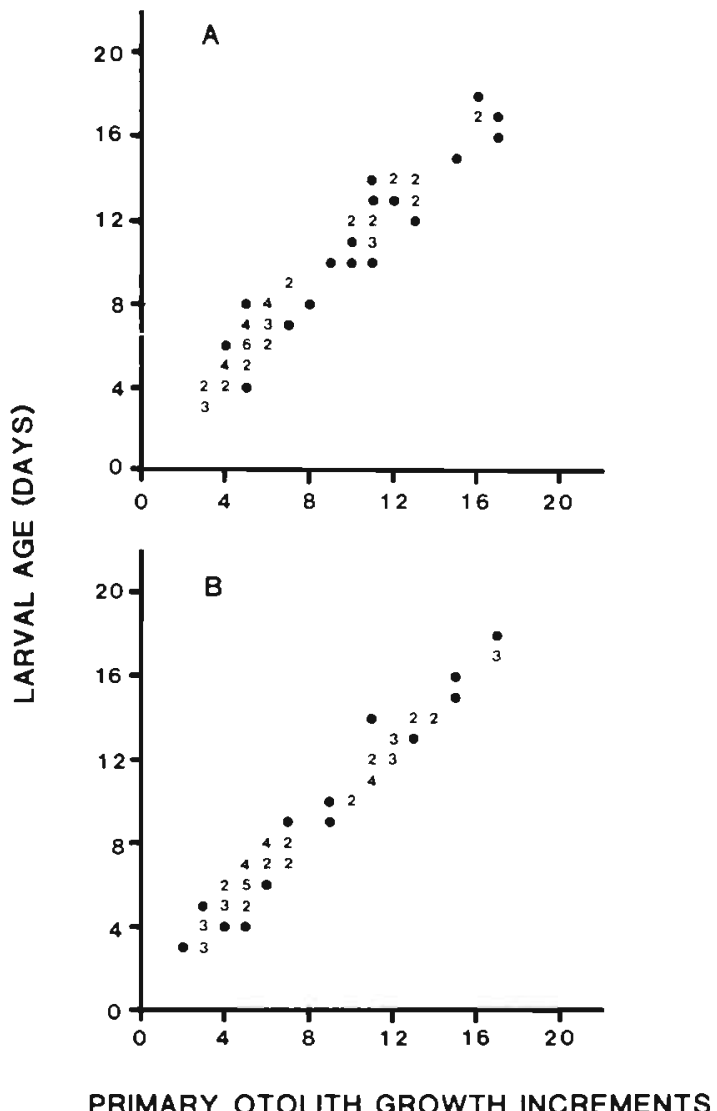

Fig. 3. Anchoa mitchilli. Relation between larval age and otolith growth increments based on laboratory-reared bay anchovy larvae. Two independent readings of the same otoliths produced Relations A and B. Dots indicate single observations. Numbers are multiple observations 
$18 \mathrm{~d}$ after hatching, were counted on 2 different dates at $1700 \times$ on a video monitor linked by television camera to a light microscope.

The good correspondence between larval age and otolith growth increments indicated that otolith increments were daily events for most larvae (Fig. 3). The relation between otolith increments and larval age was described by functional linear regressions (Ricker 1973). The regressions are:

$$
\begin{array}{rlr}
\mathrm{Y}=1.00 \mathrm{X}-0.93 & \mathrm{r}^{2}=0.94 \\
\text { and } & \\
\mathrm{Y}=1.05 \mathrm{X}-1.19 & \mathrm{r}^{2}=0.96
\end{array}
$$

for the first and second readings of the otoliths, where $\mathrm{Y}=$ number of otolith increments; $\mathrm{X}=$ larval age. The slopes did not differ from each other $(p>0.50)$ and also did not differ significantly from 1.0 , good evidence that one increment was formed per day.

Ages of larvae were predicted from numbers of increments in the rearranged equations:

$$
\begin{aligned}
& X=1.00 Y+0.93 \\
& \text { and } \\
& X=0.95 Y+1.13
\end{aligned}
$$

The y-axis intercepts of Eqns (1b) and (2b) approximately equal 1.0 increment, indicating that $1 \mathrm{~d}$ old larvae have zero increments and that the first increment is formed on the second day after hatching when the eyes become pigmented, just before larvae begin to feed. Because the 2 equations did not differ significantly and both the slope and $y$-axis intercepts were not significantly different from 1.0 , the predictive relation between age and otolith increments is:

$$
\mathrm{X}=1.00 \mathrm{Y}+1.00
$$

Age and growth. Sagittal otoliths from 184 net-collected larvae ( 39 to 55 per individual field experiment), which had been measured to the nearest $0.1 \mathrm{~mm}$ standard length, were removed, treated and examined as described for the laboratory-reared larvae. Counts of increments for each otolith were made on 2 different dates as a check on reliability. The predicted age of each larva, based on otolith increments, was obtained from Eqn (3).

Lengths of net-collected larvae for the aging, growth and mortality analyses were corrected for shrinkage. Leak (1986) developed a method, based on the observed relation between larval length and otolith diameter, to correct for shrinkage of net-collected bay anchovy larvae. Laboratory-reared larvae, which had been preserved in ethanol immediately after being sampled, probably did not shrink appreciably (Theilacker 1980). The net-collected larvae shrank 22 to $30 \%$ depending on water temperature, tow duration, air temperature and total onboard sample proces- sing time (Leak 1986). Linear regressions of corrected, 'unshrunken' lengths on age were fitted and used as growth equations. The length-weight relation for bay anchovy larvae (Houde \& Schekter 1980, 1981) was used to convert lengths to weights, from which exponential equations describing growth in weight were obtained.

Abundance corrections. The abundance of larvae in length-classes will be biased to the extent that either extrusion through net meshes or avoidance of the sampler occurs. Adjustments were made to correct these 2 sources of bias. Houde \& Lovdal (1984) determined that catches of Biscayne Bay fish larvae in a bongo net with $35 \mu \mathrm{m}$ meshes exceeded those in a paired net with 333 $\mu \mathrm{m}$ meshes because many small larvae were extruded through the larger mesh. Using their data and assuming that all small anchovy larvae were retained by the $35 \mu \mathrm{m}$ meshes, correction factors for extrusion were obtained for length classes $\leq 4.2 \mathrm{~mm}$ standard length (Table 2). The differences in catches ( $35 \mu \mathrm{m}: 333 \mu \mathrm{m}$ ) for each designated length-class were tested using the Wilcoxon paired-sample test.

Catch ratios for length classes $\leq 4.2 \mathrm{~mm}$, after correction for shrinkage, ranged from 2.2 to 6.7 times higher in the $35 \mu \mathrm{m}$ meshes (Table 2). The Table 2 correction factors were used to adjust abundances of larvae in each of the $\leq 4.2 \mathrm{~mm}$ length classes.

We had no night vs day collections of bay anchovy larvae to confirm that larger larvae could avoid the sampling gear (Smith \& Richardson 1977), but it is virtually certain that some large anchovy larvae avoided the nets (Smith 1981). Failure to account for a progressive increase in avoidance capability will lead to significant overestimation of mortality rates. To help adjust abundances caused by sampler avoidance we adopted a procedure similar to that of Yamashita et al. (1985) and used the data of Murphy \& Clutter (1972), who compared catches of larval anchovy Stolephorus purpureus collected in a $333 \mu \mathrm{m}$ mesh purse seine with catches in a $1 \mathrm{~m}$ diameter, $333 \mu \mathrm{m}$ mesh plankton net.

Table 2. Anchoa mitchill. Densities of bay anchovy larvae (number $100 \mathrm{~m}^{-3}$ ) in 5 length classes and catch ratios between $35 \mu \mathrm{m}$ and $333 \mu \mathrm{m}$ mesh nets. $\mathrm{N}$ : number of paired samples; $p$ : probability that catch ratios do not differ significantly; Wilcoxon's paired sample test

\begin{tabular}{|rrrrrrr}
$\begin{array}{c}\text { Length } \\
\text { class (mm) }\end{array}$ & \multicolumn{2}{c}{$\begin{array}{c}\text { Larval density } \\
333 \mu \mathrm{m}\end{array}$} & $\begin{array}{c}\text { Catch } \\
\text { ratio }\end{array}$ & $\mathrm{N}$ & $\mathrm{p}$ \\
\hline$<2.8$ & 48.7 & 325.7 & 6.7 & 28 & $<0.001$ \\
$2.8-3.2$ & 12.3 & 30.6 & 2.5 & 18 & 0.006 \\
$3.3-3.7$ & 6.5 & 18.0 & 2.7 & 12 & 0.091 \\
$3.8-4.2$ & 8.1 & 18.0 & 2.2 & 10 & 0.041 \\
$>4.2$ & 15.5 & 10.7 & 0.7 & 21 & 0.089 \\
\hline
\end{tabular}


Assuming that larvae did not avoid the purse seine, we fitted a regression of $\log _{e}$ catch ratio of $333 \mu \mathrm{m}$ purse seine $/ 333 \mu \mathrm{m}$ plankton net for $S$. purpureus larvae of equal lengths on larval length. The regression is

$$
\mathrm{C}=0.2690 \mathrm{e}^{0.4661 \mathrm{~L}} \quad \mathrm{r}^{2}=0.90
$$

where $\mathrm{C}=$ catch ratio; $\mathrm{L}=$ standard length $(\mathrm{mm})$. We assumed that $S$. purpureus anchovy and bay anchovy larvae of equal length had similar avoidance capability and used the regression equation to correct bay anchovy larval abundances by length class. We are reasonably confident about the assumption and believe that the adjustment procedure was effective in correcting abundance estimates for bay anchovy larvae. The correction for avoidance became increasingly important for larger larvae. Based on the catch ratio regression (Eqn 4) it was estimated that the bongo net captured only $23 \%$ of available $6.0 \mathrm{~mm}$ larvae, $6 \%$ of $9.0 \mathrm{~mm}$ larvae and $1 \%$ of $12.5 \mathrm{~mm}$ larvae.

Estimating abundance at age. To estimate survival rates abundances at length were converted to abundances to age. Bay anchovy larval catches first were separated into $0.5 \mathrm{~mm}$ length classes. The maximum and minimum lengths of larvae in each length class were corrected for shrinkage (Leak 1986) and the length-class densities (numbers $100 \mathrm{~m}^{-3}$ ) were estimated after applying the corrections for extrusion and avoidance. Age ranges (d) and age frequencies were assigned to larvae in each length class based on results of the otolith analyses and the resulting growth equations for larvae $\geq 6 \mathrm{~d}$ of age. Because the growth curves generally did not fit the data well for larvae less than $6 \mathrm{~d}$ old, lengths and ages-at-length of 3 to $5 \mathrm{~d}$ old larvae were determined by an alternative method. Their ages were estimated by assuming linear growth from $3.7 \mathrm{~mm}$ at $2 \mathrm{~d}$ after hatching (a constant value for all experiments) to the length predicted at $6 \mathrm{~d}$ after hatching based on the growth equations for each field experiment. The resulting age-length key for 3, 4, and $5 \mathrm{~d}$ old larvae for each experiment was applied to convert length-class abundances to age-class (i.e. dayclass) abundances.

Cohort mortality rates. The decline in estimated abundances of a day class with time was used to calculate each cohort's mortality rate. The method is essentially the 'converted length-frequency' technique (Essig \& Cole 1986). In our case each cohort originated from eggs spawned on a single date. Most cohorts were present on the first day of sampling during an experiment and their declining abundances were estimated on subsequent sampling days. Some cohorts first appeared as eggs or recently-hatched larvae on days after the first sampling date. Cohorts that were represented on fewer than 3 sampling dates during an experiment and cohorts that included individuals $21 \mathrm{~d}$ and older were excluded from the analyses because too few data were available to reliably estimate mortality.

Instantaneous daily mortality coefficients were estimated from an exponential model of decline:

$$
N_{t}=N_{0} e^{-Z t}
$$

where $N_{t}=$ abundance of a cohort at age $t ; N_{0}=$ the cohort's initial abundance; $Z=$ the instantaneous mortality coefficient $\left(\mathrm{d}^{-1}\right)$; and $\mathrm{t}=$ age $(\mathrm{d})$. The model was fit for the 17 or 18 cohorts examined in each field experiment (Table 3). The estimated $\log _{e}$ abundances of eggs and larvae in each day class (given as number per $\mathrm{m}^{3}$ ) were regressed on age in days. The common regression coefficient ( $Z$ ar 1974), $Z_{c}$, with its 0.95 confidence interval, also was obtained, which estimated the mean instantaneous mortality rate for each field experiment. An approximate mortality rate of eggs, which hatch 18 to $25 \mathrm{~h}$ after being spawned at temperatures recorded in these experiments, was estimated from the difference in $\log _{e}$ abundances of mid-term embryos and $1 \mathrm{~d}$ old larvae for those cohorts that included those stages. Most eggs were collected as mid-term embryos because field collections were made from mid-morning until early afternoon in each of the experiments. Spawning had occurred the previous night, with most egg production probably occurring between 2100 and 0300 h (unpubl. obs.).

Probable sources of mortality. The 2 major sources of bay anchovy early life stage mortality were believed to be predation and starvation. The mean instantane-

Table 3. Anchoa mitchilli. Numbers of bay anchovy larval cohorts examined for mortality rate determination in each of 4 Biscayne Bay field experiments. Also included are the number of dates on which a cohort was sampled and the number of samples used to estimate mortality rates

\begin{tabular}{|lrccc|}
\hline Experiment & $\begin{array}{c}\text { No. of } \\
\text { Cohorts }\end{array}$ & $\begin{array}{c}\text { No. of } \\
\text { sampling } \\
\text { dates }\end{array}$ & $\begin{array}{c}\text { Duration } \\
\text { of cohort } \\
\text { in expt (d) }\end{array}$ & $\begin{array}{c}\text { No. of } \\
\text { samples }\end{array}$ \\
\hline Sep 1979 & 11 & 6 & 11 & 6 \\
& 1 & 5 & 10 & 5 \\
& 3 & 4 & 7 & 4 \\
Apr 1980 & 2 & 3 & 5 & 3 \\
& 14 & 5 & 8 & 25 \\
May-Jun 1980 & 1 & 4 & 7 & 20 \\
& 3 & 3 & 4 & 15 \\
Aug 1980 & 15 & 5 & 7 & 25 \\
& 2 & 4 & 6 & 20 \\
& 15 & 3 & 4 & 15 \\
& 1 & 4 & 7 & 25 \\
& 2 & 3 & 6 & 20 \\
& 1 & 5 & 4 & 15 \\
\hline
\end{tabular}


Table 4. Anchoa mitchilli. Summary statistics for collections of bay anchovy eggs and larvae in North Biscayne Bay. Samples were collected in $61 \mathrm{~cm}$ bongo nets with $333 \mu \mathrm{m}$ meshes. Densities (ind $100 \mathrm{~m}^{-3}$ ) are given

\begin{tabular}{|c|c|c|c|c|c|}
\hline & Sep 1979 & Apr 1980 & May-Jun 1980 & Aug 1980 & All dates \\
\hline Sample site & A & $B-B^{\prime}$ & $\mathrm{B}-\mathrm{B}^{\prime}$ & $B-B^{\prime}$ & - \\
\hline No. of samples & 36 & 25 & 25 & 25 & 111 \\
\hline \multicolumn{6}{|l|}{ Larvae } \\
\hline Mean & 593.3 & 128.0 & 174.4 & 698.6 & 398.6 \\
\hline $\mathrm{SD}$ & 1034.2 & 142.2 & 129.5 & 479.9 & 289.5 \\
\hline $\mathrm{SE}$ & 172.4 & 28.4 & 25.9 & 96.0 & 27.5 \\
\hline \multicolumn{6}{|l|}{ Eggs } \\
\hline Mean & 1371.2 & 557.0 & 1274.4 & 6390.6 & 2398.3 \\
\hline $\mathrm{SD}$ & 1145.6 & 454.3 & 1483.9 & 7006.0 & 2686.2 \\
\hline $\mathrm{SE}$ & 190.9 & 90.9 & 296.8 & 1401.2 & 255.0 \\
\hline
\end{tabular}
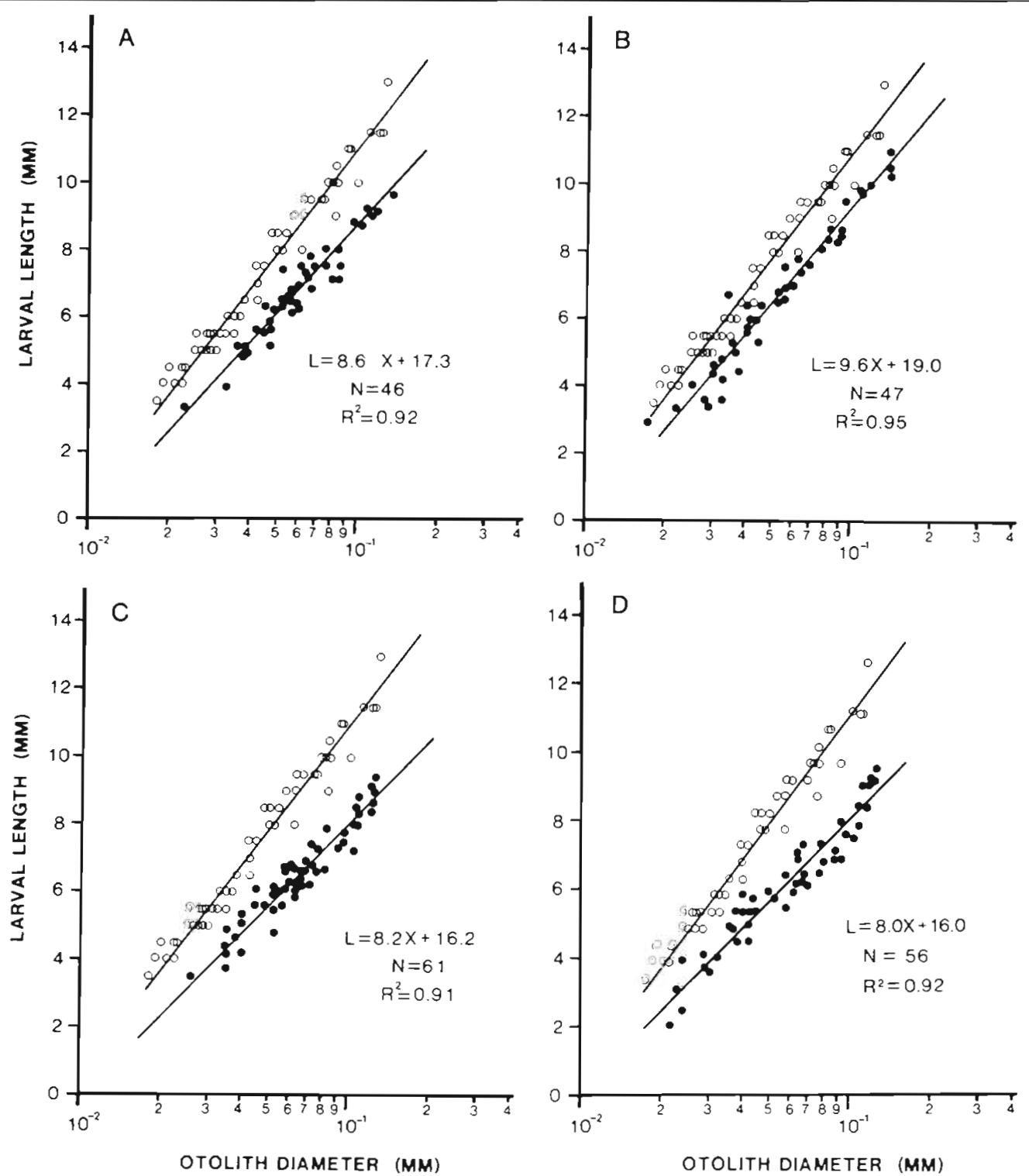

Fig. 4. Anchoa mitchilli. Linear relations between standard lengths (L) and $\log _{10}$ otolith diameters (X) for bay anchovy larvae in 4 Biscayne Bay experiments (•). (A) Sep 1979; (B) Apr 1980; (C) May-Jun 1980; (D) Aug 1980. (O) Relation for laboratory-reared larvae; repeated in each frame of the figure for comparison with field experiment results. Regression for laboratory-reared larvae is $\mathrm{L}=10.5 \mathrm{X}+21.5$ 
ous mortality coefficients (dependent variable) from each of the field experiments were included in multiple regression analysis where independent variables were (1) abundance of potential larval food, (2) abundance of 2 potential predators (chaetognaths and crab zoeae), and (3) water temperature, to determine if these variables influenced larval mortality. In a second analysis, daily instantaneous mortality was partitioned into 'starvation' and 'predation' components using laboratory-derived model results (Houde 1978) in which survival rates of bay anchovy larvae had been related to food densities. If there had been no predation on larvae in the field experiments and if advective or other losses of larvae were negligible then the fieldcollected larvae would have had the same mortality rates as laboratory-reared larvae at similar food densities. We predicted the expected survival in the field based on the density of potential microzooplankton food using Houde's (1978) model. The additional 'unexplained' instantaneous mortality that was estimated in each field experiment was then attributed to other causes, including predation.

\section{RESULTS}

\section{Egg and larvae abundances}

Bay anchovy was the most abundant taxon of fish eggs and larvae in the collections. Mean densities during the 4 experiments varied by more than an order of magnitude, ranging from 557 to 6391 eggs $100 \mathrm{~m}^{-3}$ and 128 to 699 larvae $100 \mathrm{~m}^{-3}$ (Table 4). Total numbers of bay anchovy collected were 82935 eggs and 15246 larvae. Eggs and larvae were most abundant in late summer of both 1979 and 1980 but they were common in all months sampled.

\section{Age and growth}

Larval length and $\log _{10}$ otolith diameter are linearly related (Fig. 4). Larval lengths for a given otolith diameter were consistently higher for laboratoryreared larvae because the net-collected larvae had shrunk during capture and preservation. The lengthsat-age, after correction for shrinkage (Leak 1986), were used to estimate growth rates.

The ages of 184 net-collected larvae whose otoliths were examined ranged from 3 to $23 \mathrm{~d}$ old. Larvae were 4.5 to $12.5 \mathrm{~mm}$ standard length (Fig. 5). The linear regressions in Fig. 5 are growth-in-length equations. Growth in length was linear, ranging from $0.43 \mathrm{~mm}$ $\mathrm{d}^{-1}$ in April 1980 to $0.56 \mathrm{~mm} \mathrm{~d}^{-1}$ in September 1979 (Table 5). The laboratory-reared larvae, which had been reared to validate otolith daily increment deposition, grew at $0.56 \mathrm{~mm} \mathrm{~d}^{-1}$. Instantaneous rates of growth in weight ranged from 0.23 to 0.30 (Table 5), equivalent to 25 to $35 \% \mathrm{~d}^{-1}$.

The rates of growth in length in August 1980 and September 1979 were significantly higher than those in April 1980 (analysis of covariance, $\mathrm{p}<0.001$ and SNK multiple comparison procedure, $p<0.05$ ). Predicted standard lengths at $20 \mathrm{~d}$ after hatching ranged from $12.0 \mathrm{~mm}$ (Apr 1980) to $14.0 \mathrm{~mm}$ (Sep 1979) and dry weights ranged from $903 \mu \mathrm{g}$ (Apr 1980) to $2780 \mu \mathrm{g}$ (Sep 1979) (Table 5). The ages, predicted from the growth equations, at which larvae attained $12.0 \mathrm{~mm}$ and $930 \mu \mathrm{g}$ ranged from $16.4 \mathrm{~d}$ in September 1979 to $20.0 \mathrm{~d}$ in April 1980.

No significant correlation $(0.10<\mathrm{p}<0.25)$ between anchovy larva mean growth rate (Table 5) and water temperature (Table 1) was detected, possibly because only 4 data points were available for the analysis. A general correspondence did exist, with highest growth rates occurring at the highest temperatures.

Table 5. Anchoa mitchilli. Growth equations for bay anchovy larvae from 4 experiments in North Biscayne Bay. The 0.95 confidence limits on the slope of the linear regression for growth in length and on the instantaneous growth coefficient (the exponent) for the growth-in-weight equations also are given. L: larval standard length (mm); $t$ : age in d after hatching; W: larval dry weight $(\mu \mathrm{g})$. $\mathrm{R}^{2}$ : coefficient of determination; $\mathrm{N}$ : number of larvae in analysis

\begin{tabular}{|c|c|c|c|c|c|}
\hline Experiment & Growth equation & $\begin{array}{l}0.95 \text { confidence } \\
\text { intervals }\end{array}$ & $\mathrm{R}^{2}$ & $\mathrm{~N}$ & $\begin{array}{l}\text { Predicted standard lengths }(\mathrm{mm}) \\
\text { and dry weights }(\mu \mathrm{g}) \text { at } 20 \mathrm{~d}\end{array}$ \\
\hline Sep 1979 & $\begin{array}{l}\mathrm{L}=2.83+0.56 \mathrm{t} \\
\mathrm{W}=6.89 \mathrm{e}^{0.301}\end{array}$ & $\begin{array}{l}0.51-0.61 \\
0.27-0.32\end{array}$ & 0.92 & 41 & $\begin{array}{l}14.0 \\
2780\end{array}$ \\
\hline Apr 1980 & $\begin{array}{l}\mathrm{L}=3.35+0.43 \mathrm{t} \\
\mathrm{W}=9.08 \mathrm{e}^{023 \mathrm{t}}\end{array}$ & $\begin{array}{l}0.40-0.49 \\
0.21-0.24\end{array}$ & 0.95 & 39 & $\begin{array}{c}12.0 \\
903\end{array}$ \\
\hline May-Jun 1980 & $\begin{array}{l}\mathrm{L}=3.50+0.47 \mathrm{t} \\
\mathrm{W}=9.84 \mathrm{e}^{0.25 t}\end{array}$ & $\begin{array}{l}0.43-0.53 \\
0.23-0.28\end{array}$ & 0.89 & 55 & $\begin{array}{l}12.9 \\
1460\end{array}$ \\
\hline Aug 1980 & $\begin{array}{l}\mathrm{L}=3.03+0.50 \mathrm{t} \\
\mathrm{W}=7.76 \mathrm{e}^{0271}\end{array}$ & $\begin{array}{l}0.47-0.53 \\
0.25-0.28\end{array}$ & 0.92 & 49 & $\begin{array}{l}13.0 \\
1718\end{array}$ \\
\hline
\end{tabular}



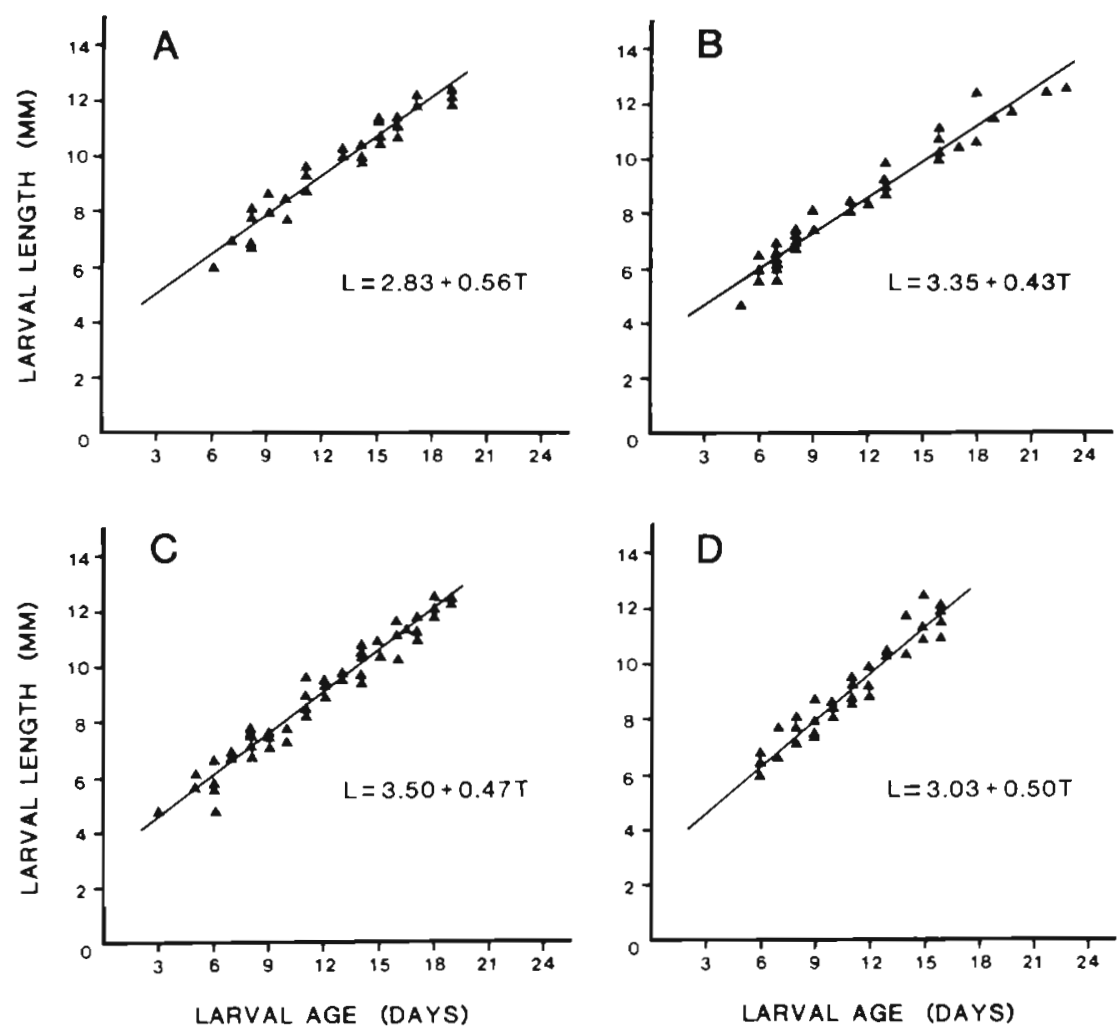

Fig. 5. Anchoa mitchilli. Linear relations between standard lengths (L), after correction for shrinkage, and age $(\mathrm{T})$ for bay anchovy larvae in 4 Biscayne Bay experiments. (A) Sep 1979; (B) Apr 1980; (C) May-Jun 1980; (D) Aug 1980
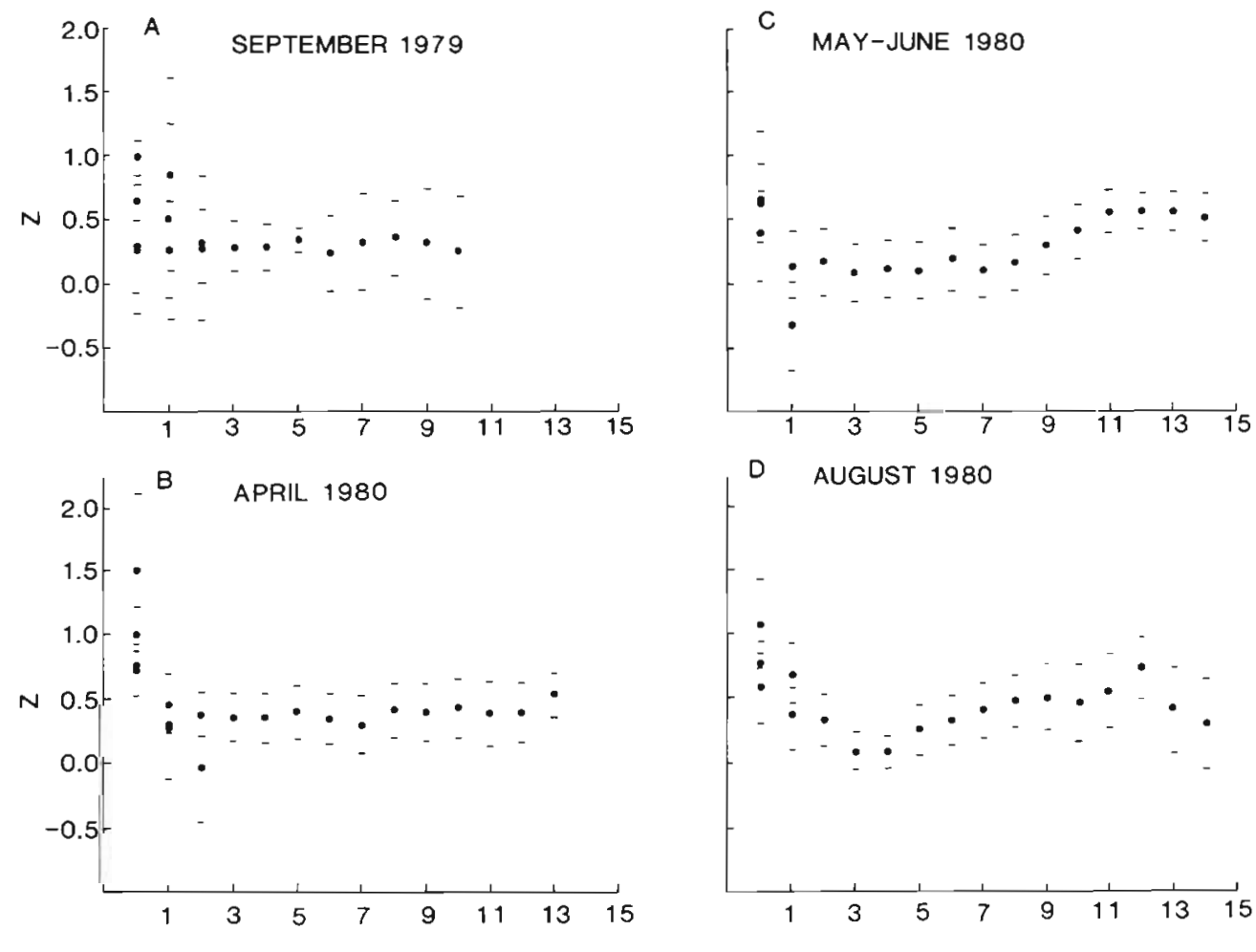

INITIAL AGE of COHORT (days)

Fig. 6. Anchoa mitchilli. Individual cohort instantaneous mortality coefficients $(Z)$ in relation to initial represented age of the cohort in samples for 4 Biscayne Bay experiments on bay anchovy eggs and larvae. Point estimates and 0.95 confidence intervals are given 


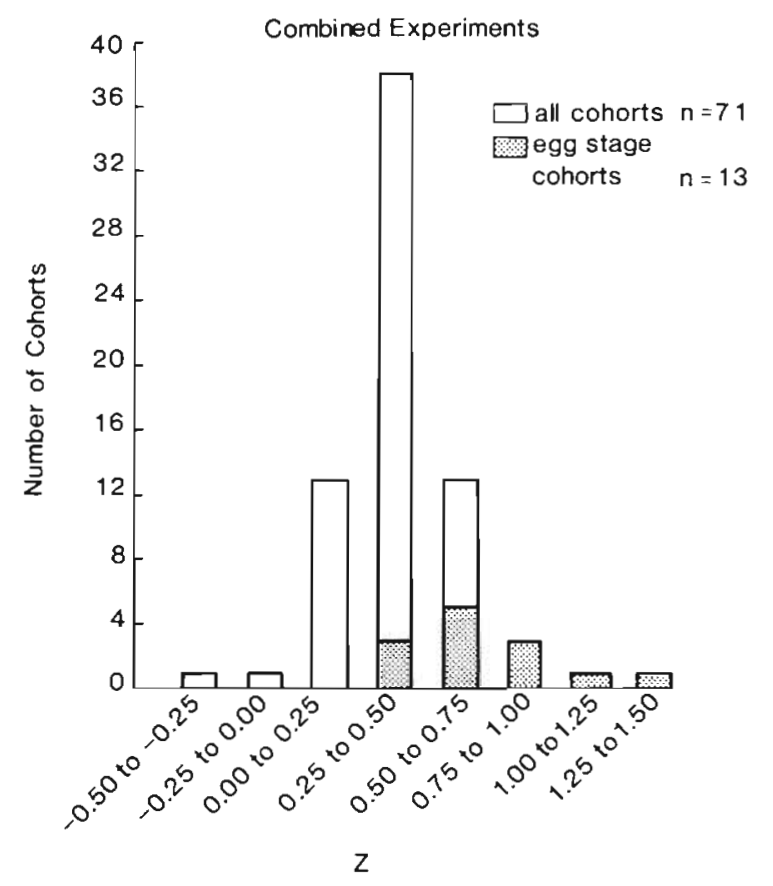

Fig. 7. Anchoa mitchilli. Combined frequency distribution of daily instantaneous mortality coefficients $(Z)$ for bay anchovy eggs and larvae collected in the 4 Biscayne Bay experiments. Stippling denotes the frequencies of $Z$ values for cohorts that included eggs

\section{Cohort mortalities}

The estimates of instantaneous daily mortality coefficients $(Z)$ for individual cohorts during the 4 field experiments ranged widely from -0.32 to 1.50 (Fig. 6). Considering all 71 estimates, $51(71.8 \%)$ fell in the range 0.25 to 0.75 (Fig. 7 ), indicating 22 to $53 \% \mathrm{~d}^{-1}$ mortality rates. The modal class of $\mathrm{Z}$ during 3 of the 4 experiments was 0.25 to 0.50 ( 22 to $39 \%$ daily mortality) (Fig. $7 \& 8$ ). Two of the 71 cohort $Z$ values were negative implying that catches of larvae from those cohorts increased at the sampling station during the course of the experiments.

The common regression coefficient $\left(Z_{c}\right)$, an estimate of the mean instantaneous mortality rate in each experiment, ranged from 0.30 (May-Jun 1980) to 0.45 (Apr 1980) (Table 6), corresponding to 26 to $36 \%$ daily losses. The weighted mean cohort-specific mortality rate for the 4 experiments was $Z=0.40$, which corresponds to a $33 \% \mathrm{~d}^{-1}$ egg and larval mortality. There were significant differences among the $Z_{c}$. The September 1979 and May-June 1980 mean mortality rates were significantly lower than those in April 1980 and August 1980 (SNK multiple comparison test, $p<0.01$ ) (Table 6). In September 1979 and May-June 1980 mean estimated mortality was 26 to $27 \% \mathrm{~d}^{-1}$ while in April 1980 and August 1980 it was 34 to $36 \% \mathrm{~d}^{-1}$.

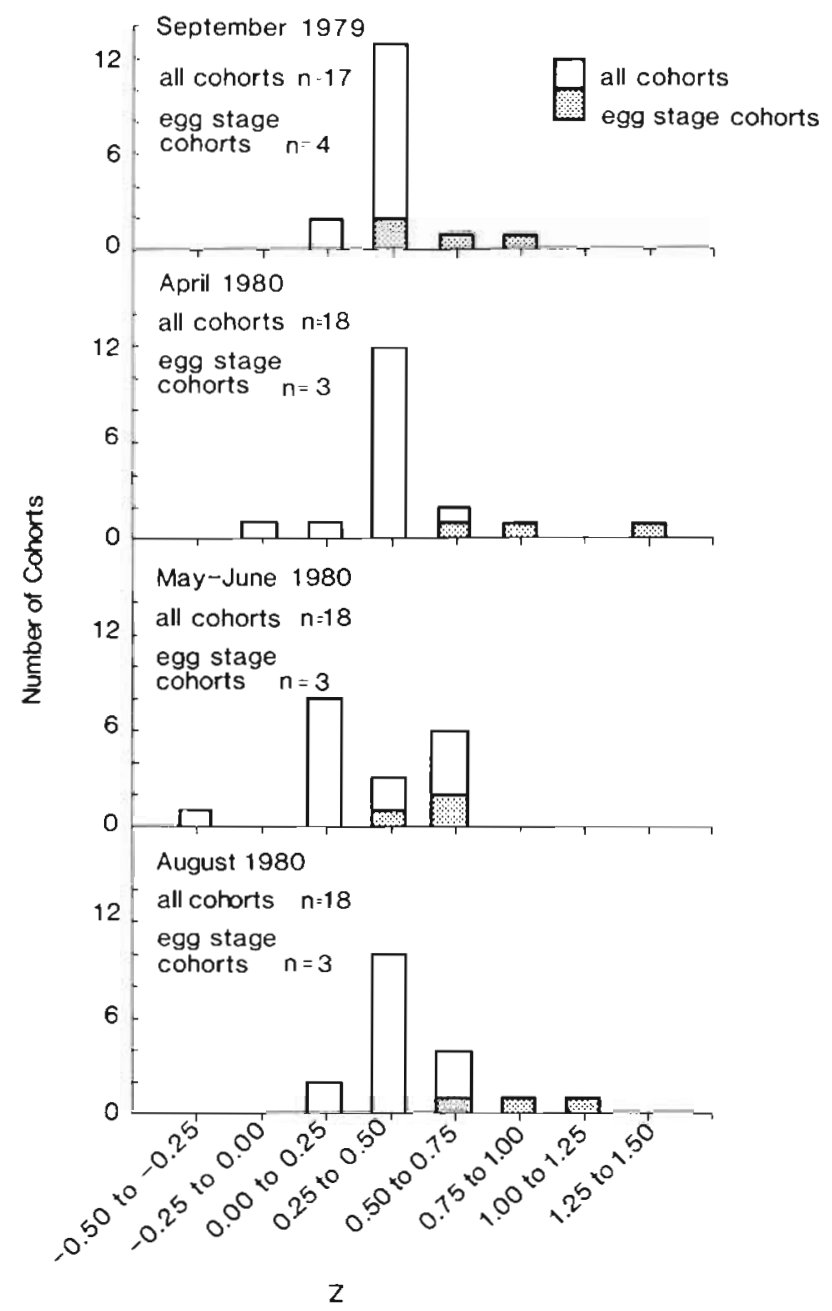

Fig. 8. Anchoa mitchilli. Frequency distributions of daily instantaneous mortality coefficients ( $Z$ ) for bay anchovy eggs and larvae collected in each of the 4 Biscayne Bay experiments. Stippling denotes the frequencies of $\mathrm{Z}$ values for cohorts that included eggs

Mean cohort relative survivorship at $20 \mathrm{~d}$ after hatching ranged from $0.012 \%$ in April 1980 to $0.248 \%$ in May-June 1980 (Table 6). Thus, based on the $Z_{c}$ estimates, predicted relative survivorship varied by a factor of 20 among the 4 field experiments. Given the initial egg density differences (Table 4) and the $Z_{c}$ values for each experiment, the estimated absolute survivorship at $20 \mathrm{~d}$ ranged from 0.07 to 3.16 larvae $100 \mathrm{~m}^{-3}$, in April 1980 and May-June 1980, respectively (Table 6). Absolute survivorship varied by a factor of 45 among experiments.

Within each experiment, the highest and lowest cohort $Z$ values differed significantly from each other (analysis of covariance and SNK multiple comparison procedure, $p<0.05$ ). The highest $Z$ values were estimated for cohorts that included eggs (Fig. 6, 7 \& 8), indicating that eggs were experiencing relatively high 
Table 6. Anchod mitchilli. Mean daily instantaneous mortality coefficients $\left(Z_{c}\right)$, estimated for each for the 4 field experiments on bay anchovy eggs and larvae from North Biscayne Bay. Also given are: predicted, relative cohort survivorships at $20 \mathrm{~d}$ after hatch (per $10^{6}$ eggs spawned); absolute mean cohort survivorships (per $100 \mathrm{~m}^{3}$ ); and cohort percent survivorship

\begin{tabular}{|lccccc|}
\hline Experiment & $\mathrm{Z}_{\mathrm{c}}$ & $\begin{array}{c}\text { Percent mortality } \\
\left(\mathrm{d}^{-1}\right)\end{array}$ & $\begin{array}{c}0.95 \text { confidence } \\
\text { interval on } \mathrm{Z}_{\mathrm{c}}\end{array}$ & $\begin{array}{c}\text { Survivorship at 20 d } \\
\text { Relative no. } \\
\left(\text { per } 10^{6}\right)\end{array}$ & $\begin{array}{c}\text { Absolute no. } \\
\left(\text { per } 100 \mathrm{~m}^{3}\right)\end{array}$ \\
\hline Sep 1979 & 0.32 & 27.4 & $0.27-0.37$ & 1661 & 2.28 \\
Apr 1980 & 0.45 & 36.2 & $0.41-0.50$ & 123 & 0.07 \\
May-Jun 1980 & 0.30 & 25.9 & $0.25-0.34$ & 2478 & 3.16 \\
Aug 1980 & 0.42 & 34.3 & $0.37-0.48$ & 255 & 1.58 \\
\hline
\end{tabular}

mortality rates. Values of $\mathrm{Z}$ from cohorts without eggs estimated larval mortality rate but not that of the entire cohort, including the egg stage. Of 13 cohorts that included eggs during the 4 experiments, 10 had $\mathrm{Z}$ values $>0.50\left(>39 \% \mathrm{~d}^{-1}\right.$ mortality) (Fig. 7). Of 58 cohorts that did not include eggs, 50 had $Z$ values $<0.50$ ( $<39 \% \mathrm{~d}^{-1}$ mortality).

Approximate egg mortality rates, estimated as the instantaneous mortalities of the stage between midterm embryo and $1 \mathrm{~d}$ old larva, were: $\mathrm{Z}=0.31$ (Sep 1979); $Z=2.21$ (Apr 1980); $Z=3.54$ (May-Jun 1980); $Z=1.71$ (Aug 1980). The highly variable mortalities in the $1 \mathrm{~d}$ period between mid-term embryo and $1 \mathrm{~d}$ old larva ranged from 26.3 to $97.1 \%$. Mean $Z$ was 1.94 , equivalent to $85.6 \%$ mortality.

There was no apparent relationship between instantaneous mortality rate and the 3 variables examined in the multiple regression analysis (i.e. potential larval food density, abundance of 2 potential larval predators, water temperature). There also was no significant correlation between the $Z_{c}$ and anchovy egg/larval abundances or between $Z_{c}$ and larval growth rates during the experiments.

\section{Probable sources of mortality}

Microzooplankton suitable as larval anchovy prey, consisting of copepod nauplii, copepodites, cirrepede nauplii, gastropod and bivalve larvae, and tintinnids, ranged from $165 \mathrm{l}^{-1}$ to $264 \mathrm{l}^{-1}$ during the 4 experiments. Laboratory model results (Houde 1978), which had predicted survival rate of anchovy larvae as a function of prey level, were applied to the field experiment data for the observed microzooplankton levels (Table 7). The estimated growth rates of North Biscayne Bay anchovy larvae exceeded $0.4 \mathrm{~mm} \mathrm{~d}^{-1}$ and the predicted lengths at $16 \mathrm{~d}$ after hatching were similar to those expected in the laboratory for similar food types and levels in 3 of the 4 cases (Table 7 ).

Predicted daily mortality rates of North Biscayne Bay larvae, based on the laboratory-derived model results, were approximately one-third the rates actually estimated (Table 7), indicating that a significant, unaccounted source of mortality or loss from the site was present. The most likely source is predation although transport/emigration losses could have occurred. The level of probable predation mortality was 1.7 to 3.2 times greater than the starvaton-related mortality. The estimated 'predation' losses ranged from $18 \% \mathrm{~d}^{-1}$ during September 1979 and May-June 1980 to 27 to $28 \% \mathrm{~d}^{-1}$ during April and August 1980.

\section{DISCUSSION}

Bay anchovy larvae deposited the first daily ring in their otoliths on the second day after hatching at $25^{\circ} \mathrm{C}$ when eyes became pigmented and feeding began. Like other anchovies, e.g. Engraulis mordax (Brothers et al. 1976) and E. japonica (Tsuji \& Aoyama 1984), deposition generally was consistent on a daily basis as long as larvae were feeding and growing (Methot \& Kramer 1979). A few of the smallest and slowest-growing bay anchovy larvae in our laboratory rearing test had 1 or 2 fewer otolith increments than larger larvae of the same age. If larvae in Biscayne Bay did not lay down rings consistently, or if otolith ring deposition were correlated with growth rate rather than age (Geffen 1982), then average age-at-length may have been underestimated and growth rates overestimated. This potential bias is not believed to be significant because food levels generally were high in the Bay and most bay anchovy larvae probably were growing at rates above the threshold where deposition of otolith rings might be interrupted.

Larvae of bay anchovy grew at rates similar to those predicted from growth models developed in the laboratory, which related anchovy growth rates to food concentration (Houde 1978, Houde \& Schekter 1981). At the microzooplankton levels of 165 to $264 \mathrm{l}^{-1}$ observed in North Biscayne Bay, larvae were predicted to grow in excess of $0.40 \mathrm{~mm} \mathrm{~d}^{-1}$ (Houde \& Schekter 1981). The estimated rates for North Biscayne Bay 
Table 7. Anchoa mitchilli. Standard lengths at $16 \mathrm{~d}$ after hatching and mortality rates of bay anchovy larve estimated from North Biscayne Bay field data and predicted from laboratory-derived growth and mortality models (Houde 1978), which predict length and survival at $16 \mathrm{~d}$ as functions of microzooplankton prey level

\begin{tabular}{|c|c|c|c|c|c|c|}
\hline \multirow[t]{3}{*}{ Experiment } & \multirow{3}{*}{$\begin{array}{c}\text { Microzooplankton } \\
\left(\text { no. } 1^{-1} \text { ) }\right.\end{array}$} & \multicolumn{4}{|c|}{ Bay anchovy } & \\
\hline & & \multicolumn{2}{|c|}{ Standard length $(\mathrm{mm})$} & \multicolumn{3}{|c|}{ Instantaneous daily mortality rate $(Z)$} \\
\hline & & Field data & Lab model & $\begin{array}{l}\text { Field data } \\
\text { (A) }\end{array}$ & $\begin{array}{c}\text { Lab model } \\
\text { (B) }\end{array}$ & $\begin{array}{l}\text { Difference } \\
\qquad(A-B)\end{array}$ \\
\hline Sep 1979 & 171.8 & 11.8 & 10.6 & 0.32 & 0.12 & 0.20 \\
\hline Apr 1980 & 165.1 & 10.2 & 10.6 & 0.45 & 0.12 & 0.33 \\
\hline May-Jun 1980 & 263.6 & 11.0 & 11.1 & 0.30 & 0.10 & 0.20 \\
\hline Aug 1980 & 250.0 & 11.0 & 11.0 & 0.42 & 0.10 & 0.32 \\
\hline
\end{tabular}

cohorts did range from 0.43 to $0.56 \mathrm{~mm} \mathrm{~d}^{-1}$. Estimated lengths of Biscayne Bay larvae at $16 \mathrm{~d}$ after hatching also closely approximated lengths predicted from the laboratory model (Houde 1978; Table 7), except in September 1979 when Biscayne Bay larvae grew faster than predicted. The laboratory data (Houde 1978) had been obtained at $26.0>\mathrm{C}$. Mean in situ temperatures ranged from 24.4 to $30.7>\mathrm{C}$ during the 4 field experiments. Temperatures $>26>\mathrm{C}$ probably had a positive influence on growth rates although we were unable to demonstrate a statistically significant correlation between mean growth rates and temperatures for the 4 data points available. The generally good correspondence between laboratory and field growth rates relative to prey concentration increased our confidence that the relationship between in situ larval survival and prey concentration, in the absence of mortality from sources other than starvation, also would approximate the laboratory model results. This assumption allowed us to partition total mortality into its starvation and 'predation plus other sources' components.

Mortality rates of egg and larval cohorts of bay anchovy were high and variable, daily mortalities usually ranging from 22 to $39 \% \mathrm{~d}^{-1}(\mathrm{Z}=0.25$ to 0.50$)$. At the mean mortality rates in these experiments (Tables 6 \& 7) the estimated relative survivorship of cohorts at $20 \mathrm{~d}$ of age already varied by a factor of 20 . Because the initial egg densities varied among experiments, absolute cohort survivorhip at $20 \mathrm{~d}$ was estimated to vary by at least 45 times. The mortality rates that we estimated were higher than rates recorded for most marine fish larvae (Bannister et al. 1974, Harding et al 1978, Dahlberg 1979, Blaxter \& Hunter 1982, Hewitt \& Methot 1982, Graham \& Townsend 1985, Lough et al. 1985 , Smith 1985), although Hewitt et al. (1985) recently reported high mortality rates for jack mackerel eggs and larvae that resulted in $>99 \%$ loss before the end of the yolk-sac stage.
Daily cohorts that included the egg stage experienced cohort-specific mortality rates that were higher than rates for cohorts that first appeared in samples at older ages. The high mean and modal mortality rates observed for 'egg-stage' cohorts indicated that a significant part of the mortality experienced by a bay anchovy cohort may occur before hatching, a period of $24 \mathrm{~h}$ or less for bay anchovy at temperatures $\geq 26^{\circ} \mathrm{C}$. The modal mortality range for 'egg-stage' cohorts was 39 to $52 \% \mathrm{~d}^{-1}$, approximately $15 \% \mathrm{~d}^{-1}$ higher than the modal range when all cohorts were considered. More than $90 \%$ of a cohort may die before completion of the yolk-sac stage, after which larvae experience lower mortality rates. Egg stage mortality of clupeoids generally is high, reported values ranging from 13 to $93 \% \mathrm{~d}^{-1}$ (Dahlberg 1979). Northern anchovy eggs suffered a $32 \% \mathrm{~d}^{-1}$ mortality rate in 1980 (Stauffer \& Picquelle 1981) and generally have mortality rates in excess of $20 \% \mathrm{~d}^{-1}$ (Lo 1985b). The Peru anchoveta Engraulis ringens suffered daily egg mortality of $68 \%$ $\mathrm{d}^{-1}$ in August/September 1981 (Alheit 1986). Because northern anchovy and Peru anchoveta eggs require more than $2 \mathrm{~d}$ to hatch (Lo 1985a), while bay anchovy hatches in $1 \mathrm{~d}$ or less, total egg mortalities are quite similar among the species.

The relatively high mortality rates experienced by egg-stage cohorts did not extend to cohorts first sampled as yolk-sac larvae (1 d old larvae), suggesting that eggs are the most vulnerable stage during bay anchovy early life. Nine cohorts that were first sampled as yolksac larvae experienced a mean mortality of $30 \% \mathrm{~d}^{-1}$ and had the same modal instantaneous coefficient range $(Z=0.25$ to 0.50$)$ as cohorts that consisted entirely of older larvae. This observation differed from that for northern anchovy in which both egg and yolksac larvae (embryonic stages) have mortality rates higher than those of older larvae (Lo 1985b, Smith 1985). In a single in situ experiment, Fortier \& Leggett 
(1985) reported $43.7 \% \mathrm{~d}^{-1}$ mortality of capelin Mallotus villosus yolk-sac larvae and suggested that the high mortality at the end of the yolk-sac stage might be indicative of a critical period (sensu Hjort 1914). There was no evidence from our study that the yolk-sac period was 'critical' in bay anchovy.

Cohort-specific mortality rates, rather than averaged rates based on an assumed stable age distribution, were estimated in each experiment. This approach was preferred because daily spawning was highly variable. The coefficients of variation for egg densities were aproximately $100 \%$ in each experiment (Table 4). Under those conditions a stable age distribution assumption was unrealistic. Cohorts varied significantly in abundance. An advantage of the cohortspecific approach was that the frequency distribution of mortality rates was obtained (Fig. $7 \& 8$ ), facilitating comparison of cohort mortality and its variability both within and among experiments.

Cohort-specific mortality rates for larvae first sampled at $1 \mathrm{~d}$ of age and older were surprisingly consistent within the several days encompassed by each of the 4 experiments (Fig. 6). The relatively stable estimates of $Z$ in each of the experiments supports our belief that mortality rates were reliably estimated and not unduly influenced by unaccounted escapement or avoidance losses. Small apparent increases in $\mathrm{Z}$ for cohorts first sampled at $7 \mathrm{~d}$ of age and older in MayJune and August 1980 (Fig, 6) indicated that cohort mortality rates were lower for the cohorts first sampled at younger ages during those experiments. If avoidance losses were not fully accounted, they could have contributed to an apparent increased mortality, which would have been most apparent in the cohorts first sampled at several days after hatching.

Mortality from predation may have been higher and more variable than that caused by starvation for early life stages of bay anchovy. The high mortalities during the egg and yolk-sac stages could not have been starvation-related because yolk was the source of nutrition for these stages. Because stage duration was brief (less than $2.5 \mathrm{~d}$ from spawning to end of yolk-sac stage) advection also was an unlikely major cause of loss. Thus, predation appeared to be the major cause of mortality for eggs and yolk-sac larvae. For older larvae, the presumed predation-related mortality continued to be most important, based on the predictions of a food-dependent survival model derived from laboratory experiments (Houde 1978).

We did not identify predators on anchovy eggs or larvae although both invertebrates and fishes potentially could be important. The ctenophore Mnemiopsis mccradyi was abundant. Its abundance (indexed by volume) averaged $7.5 \mathrm{ml} \mathrm{m}^{-3}$ during the 4 experiments and it potentially could have been an important preda- tor on anchovy eggs (see Hunter 1984 for review of egg/larval predators). Crab zoeae and chaetognaths also were possible predators at the sampling site. Cannibalism of eggs and larvae by juvenile and adult bay anchovy may be a significant factor in Biscayne Bay, much as it is for eggs and larvae of northern anchovy (Hunter \& Kimbrell 1980, MacCall 1980) or Peru anchoveta (Alheit 1986). The high densities of bay anchovy eggs, 557 to 6391 per $100 \mathrm{~m}^{3}$, during the 4 experiments indicated that adult anchovies were abundant at the Biscayne Bay study site. Dowd (1986) and Brownell (1985) have studied predation by juvenile and post larval anchovies on larval fish in the laboratory and have demonstrated that they can inflict significant predation mortality.

Results of this study have addressed both levels and sources of mortality to embryos and larvae. Bay anchovy eggs and larvae sustained high mortality rates. Apparent predation accounted for 18 to $28 \% \mathrm{~d}^{-1}$ losses, levels 2 to 3 times higher than those attributed to starvation-related mortality. However, both sources of mortality were high and significant. The similarity among experiments of the mortality rates predicted to be starvation-related (Table 7 ) reflect the small range of mean microzooplankton densities in the 4 experiments. Small changes in predator abundances or moderate declines in food levels could change survival rates significantly (Houde 1978) and alter cohort recruitment success (Houde in press). Annual recruitment levels in bay anchovy and many serial spawning fish depend on the cumulative effects of predation on embryos and larvae, and the food available to larvae over a protracted spawning season. A small but sustained shift in the level of either factor could cause annual recruitments to vary significantly (Houde in press) or limit recruitment to small parts of the spawning season when survival conditions are favorable, as observed for northern anchovy (Methot 1983). Differences among the experiments in egg/larval survival and growth rates of bay anchovy were high enough to lead to seasonally variable recruitment potential. In Biscayne Bay predation was implicated to be a more variable and potentially more influential regulator of bay anchovy recruitment than was starvation mortality.

Acknowledgements. Support for this research was provided by the National Science Foundation, Grants OCE 80-07807 and OCE 81-08021, to the second author and by a research fellowship from the Reitmeister Foundation to the senior author while he studied for his Ph. D. at the Rosenstiel School for Marine and Atmospheric Science, University of Miami. We sincerely appreciate technical assistance in the laboratory and in the field by K. Bond, C. Bourque, and J. Lovdal. E. J. Chesney, Jr, reviewed an early draft of the manuscript. Parts of this paper are derived from a Ph. D. dissertation, submitted by J. C. Leak to the Graduate School, University of Miami, Coral Gables. 


\section{LITERATURE CITED}

Alheit, J. (1986). Egg cannibalism versus egg predation: their significance in anchovies. Coun. Meet. int. Coun. Explor. Sea C.M.-ICES/59: 1-5

Bannister, R. C. A., Harding, D., Lockwood, S. J. (1974). Larval mortality and subsequent year-class strength in the plaice (Pleuronectes platessa L.). In: Blaxter, J. H. S. (ed.) The early life history of fish. Springer-Verlag, New York, p. 21-37

Bigelow, H. B., Schroeder, W. C. (1953). Fishes of the Gulf of Maine. Fish. Bull. U.S. 53: 1-57

Blaxter, J. H. S., Hunter, J. R. (1982). The biology of the clupeoid fishes. In: Blaxter, J. H. S., Russel, F. S., Yonge, M. (ed.) Adv. Mar. Biol. 20: 1-223

Brothers, E. B., Mathews, C. P., Lasker, R. (1976). Daily growth increments in otoliths from larval and adult fishes. Fish. Bull. U.S. 74: 1-8

Brownell, C. L. (1985). Laboratory analysis of cannibalism by larvae of the cape anchovy Engraulis capensis. Trans. Am. Fish. Soc. 114: 512-518

Crecco, V. A., Savoy, T. F. (1985). Effects of biotic and abiotic factors on growth and relative survival of young American shad, Alosa sapidissima, in the Connecticut River. Can J. Fish. Aquat. Sci. 42: 1640-1648

Cushing, D. H. (1975). Marine ecology and fisheries. Cambridge University Press, Cambridge

Dahlberg, M. D. (1979). A review of survival rates of fish eggs and larvae in relation to impact assessments. Mar. Fish. Rev. 41(3): 1-12

Detwyler, R., Houde, E. D. (1970). Food selection by laboratory-reared larvae of the scaled sardine Harengula pensacolae (Pisces, Clupeidae) and the bay anchovy Anchoa mitchilli (Pisces, Engraulidae). Mar. Biol. 7: 214-222

Dovel, W. L. (1971). Fish eggs and larvae of the upper Chesapeake Bay. Univ. Maryland, Natural Resources Institute, Spec. Rep. 4: 1-71

Dovel, W. L. (1981). Ichthyoplankton of the lower Hudson estuary, New York. New York Fish and Game J. 28: 21-39

Dowd, C. E. (1986). Predator-prey interactions between juvenile bay anchovy (Anchoa mitchilli) and larvae of the sea bream (Archosargus rhomboidalis). Ph. D. dissertation, Univ. of Miami, Coral Gables

Essig, R. J., Cole, C. F. (1986). Methods of estimating larval fish mortality from daily increments in otolihs. Trans. Am. Fish. Soc. 115: 34-40

Flores-Coto, C., Barba-Torres, F., Sanchez-Robles, J. (1983). Seasonal diversity, abundance and distribution of ichthyoplankton in Tamiahua Lagoon, western Gulf of Mexico. Trans. Am. Fish. Soc. 112: 247-256

Fortier, L., Leggett, W. C. (1985). A drift study of larval fish survival. Mar. Ecol. Prog. Ser. 25: 245-257

Geffen, A. J. (1982). Otolith ring deposition in relation to growth rate in herring (Clupea harengus) and turbot (Scophthalmus maximus) larvae. Mar. Biol. 71: 317-326

Graham, J. J., Townsend, D. W. (1985). Mortality, growth, and transport of larval Atlantic herring Clupea harengus in Maine coastal waters. Trans. Am. Fish. Soc. 114: 490-498

Harding, D., Nichols, J. H., Tungate, D. S. (1978). The spawning of plaice (Pleuronectes platessa L.) in the southern North Sea and English Channel. Rapp. P.-v. Réun. Cons. int. Explor. Mer 172: 102-113

Hela, I., Carpenter, C., McNulty, N. K. (1957). Hydrography of a positive, shallow, tidal bar-built estuary. Bull. mar. Sci 7: $47-99$

Hewitt, R. P., Methot, R. D., Jr. (1982). Distribution and mor- tality of northern anchovy larvae in 1978 and 1979. Cal. Coop. Oceanic Fish. Invest. Rep. 23: 226-245

Hewitt, R. P., Theilacker, G. H., Lo, N. C. H. (1985). Causes of mortality in young jack mackerel. Mar. Ecol. Prog. Ser. 26: $1-10$

Hjort, J. (1914). Fluctuations in the great fisheries of northern Europe. Rapp. P.-v. Réun. Cons. int. Explor. Mer 20: 1-228

Houde, E. D. (1977). Food concentration and stocking density effects on survival and growth of laboratory-reared larvae of bay anchovy Anchoa mitchilli and lined sole Achirus lineatus. Mar. Biol. 43: 333-341

Houde, E. D. (1978). Critical food concentrations for larvae of three species of subtropical marine fishes. Bull. mar. Sci. 28: 395-411

Houde, E. D. (in press). Fish early life dynamics and recruitment variability. Trans. Am. Fish. Soc.

Houde, E. D., Lovdal, J. D. (1984). Seasonality of occurrence, foods and food preferences of ichthyoplankton in Biscayne Bay, Florida. Estuar. coast. Shelf Sci. 18: 403-419

Houde, E. D., Schekter, R. C. (1980). Feeding by marine fish larvae: developmental and functional responses. Environ. Biol. Fish. 5: 315-334

Houde, E. D., Schekter, R. C. (1981). Growth rates, rations and cohort consumption of marine fish larvae in relation to prey concentrations. Rapp. P.-v. Réun. Cons. int. Explor. Mer 178: 441-453

Hunter, J. R. (1981). Feeding ecology and predation of marine fish larvae. In: Lasker, R. (ed.) Marine fish larvae: morphology, ecology and relation to fisheries. Washington Sea Grant Program, Univ. Washington Press, Seattle, p. 33-77

Hunter, J. R. (1984). Inferences regarding predation on the early life stages of cod and other fishes. In: Dahl, E., Danielssen, D. S., Moksness, E., Solemdal, P. (ed.) The propagation of cod Gadus morhua L. Institute of Marine Research, Bergen, Norway. Flodevigen Rapportser 1: $533-562$

Fiunier, J. R., Kimbrell, C. A. (1380). Egg cannibalism in the northern anchovy, Engraulis mordax. Fish. Bull. U.S. 78: $811-816$

Leak, J. C. (1986). The relationship of standard length and otolith diameter in larval bay anchovy, Anchoa mitchilli (Val.). A shrinkage estimator. J. exp. mar. Biol. Ecol. 95: $167-172$

Lo, N. C. H. (1985a). A model for temperature-dependent northern anchovy egg development and an automated procedure for the assignment of age to staged eggs. In: Lasker, R. (ed.) An egg production method for estimating spawning biomass of pelagic fish: application to the northern anchovy, Engraulis mordax. U.S. Dept. Commerce, NOAA Tech. Rep. NMFS 36: 43-50

Lo, N. C. (1985b). Egg production of the central stock of northern anchovy, Engraulis mordax, 1951-82. Fish. Bull. U.S. 83: $137-150$

Lough, R. C., Bolz, G. R., Pennington, M., Grosslein, M. D. (1985). Larval abundance and mortality of Atlantic herring (Clupea harengus L.) spawned in the Georges Bank and Nantucket Shoals areas, 1971-78 seasons, in relation to spawning stock size. J. NW Atlan. Fish. Sci. 6: 21-35

MacCall, A. D. (1980). The consequences of cannibalism in the stock-recruitment relationship of planktivorous pelagic fishes such as Engraulis. In: Sharp, G. D. (ed.) Workshop on the effects of environmental variation on the survival of larval pelagic fishes. UNESCO, Int. Oceanogr. Commission Workshop Rep. 28: 201-220

Methot, R. D., Jr. (1983). Seasonal variation in survival of larval northern anchovy, Engraulis mordax, estimated 
from the age distribution of juveniles. Fish. Bull. U.S. 81: $741-750$

Methot, R. D., Jr., Kramer, D. (1979). Growth of northern anchovy, Engraulis mordax, larvae in the sea. Fish. Bull U.S. 77: 413-423

Murphy, G. I., Clutter, R. I. (1972). Sampling anchovy larvae with a plankton purse seine. Fish. Bull. U.S. 70: 789-798

Pearson, J. C. (1941). The young of some marine fishes taken in lower Chesapeake Bay, Virginia, with special reference to the grey seatrout, Cynoscion regalis (Bloch). Fish. Bull. U.S. 50: 79-102

Ricker, W. E. (1973). Linear regressions in fishery research. J. Fish. Res. Bd Can. 30: 409-434

Smith, P. E. (1981). Fisheries on coastal pelagic schooling fish. In: Lasker, R. (ed.) Marine fish larvae. Morphology, ecology and relation to fisheries. Washington Sea Grant Program, Univ. Washington Press, Seattle, p. 1-13

Smith, P. E. (1985). Year-class strength and survival of Ogroup clupeoids. Can. J. Fish. Aquat. Sci. 42 (Suppl. 1): 69-82

Smith, P. E., Richardson, S. L. (1977). Standard techniques for pelagic fish egg and larvae surveys. F.A.O. Fish. Tech. Pap. 175: 1-100
Stauffer, G. D., Picquelle, J. (1981). Estimates of the 1980 spawning biomass of the central subpopulation of northern anchovy. Cal. Coop. Oceanic Fish. Invest. Rep. 22: 8-13

Struhsaker, P., Uchiyama, J. H. (1976). Age and growth of the nehu, Stolephorus purpureus (Pisces: Engraulidae), from the Hawaiian Islands as indicated by daily growth increments of sagittae. Fish. Bull. U.S. 74: 9-17

Theilacker, G. H. (1980). Changes in body measurements of larval northern anchovy, Engraulis mordax, and other fishes due to handling and preservation. Fish. Bull. U.S. 78: 685-692

Tsuji, S., Aoyama, T. (1984). Daily growth increments in otoliths of Japanese anchovy larvae Engraulis japonica. Bull. Jap. Soc. scient. Fish. 50: 1105-1108

Yamashita, Y., Kitagawa, D., Aoyama, T. (1985). A field study of predation of the hyperiid amphipod Parathemisto japonica on larvae of the Japanese sand eel Ammodytes personatus. Bull. Jap. Soc. scient. Fish. 51: 1599-1607

Zar, J. H. (1974). Biostatistical analysis. Prentice-Hall, Inc, Englewood Cliffs, New Jersey

This article was presented by Dr. K. Sherman; it was accepted for printing on February 18, 1987 